\title{
TEMPORAL TRENDS IN THE DETECTION RATES OF HEPATITIS B IN THE SANTA CATARINA STATE, BRAZIL
}

Chaiana Esmeraldino Mendes MARCON(1), Ione Jayce Ceola SCHNEIDER(2) \& Jefferson TRAEBERT(3)

\begin{abstract}
SUMMARY
Hepatitis B is a serious public health problem. The state of Santa Catarina presents areas of high endemicity. The aim of this study was to describe temporal trends in detection rates of hepatitis B in the period from 2002 to 2009 in Santa Catarina and in its regions. A time series study was carried out. Crude rates were calculated and standardized by age using the direct method. Annual variation percentages were estimated by Joinpoint regression. There were two distinct and significant trends in Santa Catarina. From 2002 to 2006 a significant increase of 5.9\% per year was observed. From 2006, there was a significant decrease of $6.4 \%$ per year. In this same period the southern and far-western regions had significant increases of $15.9 \%$ and $4.6 \%$ and significant decreases of $7.5 \%$ and $4.8 \%$, respectively. Greater Florianópolis and Northeast also showed significant increases until 2006, of 15.4\% and 17.4\%, respectively. In the following period, non-significant decreases of $5.8 \%$ and $9.8 \%$ respectively were observed. Foz do Rio Itajaí and Planalto Serrano showed non-significant increases up to half of the studied period of $21.1 \%$ and $12.0 \%$, respectively and after, significant decreases of $21.5 \%$ and $18.0 \%$, respectively. Vale do Itajaí showed a significant decrease of $9.7 \%$; Planalto Norte showed a non-significant decrease of $0.6 \%$ and Midwest a non-significant increase of $2.7 \%$ per year, in the period from 2002 to 2009.
\end{abstract}

KEYWORDS: Hepatitis B; Epidemiology; Temporal distribution.

\section{INTRODUCTION}

Hepatitis B is considered a serious public health problem all over the world. The disease affects both genders, but infections in females require special attention due to the possibility of vertical transmission. The presence of $\mathrm{HBV}$ in the semen and in vaginal secretion means that transmission is enabled by sexual intercourse. The contamination also may occur by sharing syringes, occupational exposure, contaminated blood transfusion and through family life habits ${ }^{3,12,13}$.

Approximately two billion people are contaminated by HBV and 350 million, or $5 \%$ of the world population, have developed chronic forms of hepatitis $\mathrm{B}^{19}$. According to the World Health Organization (WHO), China and the rest of Asia are areas of high endemicity. The Amazon Region and Central Europe have high rates of chronic disease. The WHO estimates that 2\% to 5\% of the general population of the Middle East and the Indian Subcontinent are chronically infected with hepatitis $\mathrm{B}^{19}$. The Brazilian Health Ministry estimates that $15 \%$ of the Brazilian population has already had contact with $\mathrm{HBV}$ and about $1 \%$ of the population has developed a chronic form of the disease ${ }^{10,11}$. A greater prevalence is found in the Northern region, however studies performed in 1980 and 1990 showed a growing trend in the South, in the Amazonian Region and in some towns from Espírito Santo 5 .
A population-based cross-sectional study carried out in 26 of the Brazilian state capitals and in the Federal District between 2005 and 2009 showed $7.4 \%$ seropositivity for anti-HBc infection in the age group 1069 years old, indicating low endemicity. The region had a prevalence of $9.59 \%$ and a higher detection rate in 2010, that reached $14.3 / 100$ thousand inhabitants; Florianópolis was the capital with the highest detection rate in the region with 21.1/100 thousand inhabitants ${ }^{4}$. The west region of Santa Catarina state presents high endemicity ${ }^{5,7}$ mainly in the regions of Chapecó, São Miguel do Oeste and Concórdia where the detection rates have varied between 67.77/100 thousand habitants in 2006 and 54.81/100 thousand habitants in $2010^{17}$.

The aim of this study was to describe the temporal trend of detection rates of hepatitis B in the period from 2002 to 2009 in the state of Santa Catarina and in its health regions.

\section{MATERIAL AND METHODS}

A time series study was carried out using notified cases of hepatitis B in the state of Santa Catarina from 2002 to 2009. Notification data was obtained through the Brazilian National Case Registry Database of Brazilian Health Ministry. 


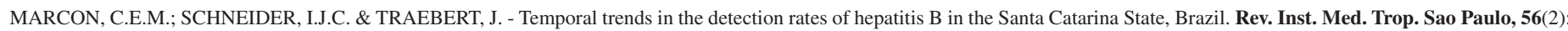
$151-5,2014$

Estimates regarding the resident population of the state and its health regions were obtained from the censuses or inter-censuses dataset and were used as denominators for the detection rate calculation. Initially, crude rates of notification of hepatitis B were calculated. Next, they were standardized by age using the direct method and the population of Santa Catarina in 2010 as the standard.

The standard rates were used in the trend analysis through an estimation of regression models. For the modeling process, standard rates $(y)$ were the dependent variable, and the years of the period in the study were the independent variable $(\mathrm{x})$.

After analyzing the historical series and the oscillation due to the small number of cases in some periods, the decision was made to calculate the moving mean based on three terms. During this process, the coefficient of each year was determined by the arithmetic mean of coefficients of the previous year, of the year itself and of the next year. This resulted in the presentation of data of years from 2002 to 2009, although data from 2001 to 2010 had been used.

The software Joinpoint (Statistical Research and Applications Branch, National Cancer Institute, Rockville, MD, USA) version 3.5.4 was used, to compute the annual variation of notifications in the period from 2002 to 2009. The software executes a segmented linear regression (joinpoint regression) to estimate the percentage of annual variation and identify points where there is modification of a trend. The models in which a different number of trend modification "points" from 0 (case in which the trend is represented by a single line segment) were assumed and adjusted successively until the maximum number was two. The model chosen was the one with the highest number of points in which the statistical significance $(p<0.05)$ was maintained. The annual variation in percentage (AVP) was calculated from the estimated inclination for each line segment (regression coefficient). Its statistical significance was estimated by the method of least-squares through a generalized linear model, assuming that rates follow a distribution of Poisson, since the rates variation were not constant along the periods. For each line segment $95 \%$ confidence intervals $(95 \% \mathrm{CI})$ were calculated.

\section{RESULTS}

In the studied period, 9,421 cases of hepatitis B were detected in Santa Catarina. The number of detected cases by health regions is shown in Table 1.

Two significant trends were observed in the state of Santa Catarina in the studied period. In the first one, from 2002 to 2006, a significant increase of $5.9 \%$ per year $(95 \%$ CI $3.6 ; 8.3)$ was observed in the notification rates. From 2006, there was an inversion of the trend with a significant decrease of $6.4 \%$ per year $(95 \%$ CI $-9.7 ;-3.1)$. The same behavior was observed in the southern and far-western health regions. In the period as a whole, (2002 to 2009) only in the southern region a significant increase of $5.2 \%$ per year $(95 \%$ CI $4.2 ; 6.2)$ was observed (Table 2 and Fig. 1).

In the health regions of North-east and Greater Florianópolis significant increases in the years from 2002 to 2006 were observed, but a decrease in rates in the subsequent period proved to be insignificant. Two distinct trends were also observed in the health region of Foz do
Table 1

Number of detected cases of hepatitis B by health regions in the 2002 to 2009 period

\begin{tabular}{lc}
\hline HEALTH REGION & DETECTED CASES \\
\hline Far West & 3,492 \\
Foz do Rio Itajaí & 74 \\
Planalto Serrano & 81 \\
Northeat & 508 \\
Great Florianópolis & 1,180 \\
South & 848 \\
Planalto Norte & 1,221 \\
Mid West & 1,162 \\
Vale do Itajaí & 855 \\
Santa Catarina & 9,421 \\
\hline
\end{tabular}

Rio Itajaí, with a significant decrease in the period from 2004 to 2009 , but with no significant statistical trend in the anterior period of study. The same occurred in the Planalto Serrano. However, the period of significant decrease was from 2005 to 2009 , which was enough to result in a significant decrease of $6.3 \%$ per year $(95 \%$ CI $-11.9 ;-0.3)$ in the period from 2002 to 2009 (Table 2 and Fig. 1).

In the Planalto Norte, Midwest and Vale do Itajaí health regions only one trend was observed. Nevertheless, only the latter presented a significant trend with a decrease of $9.7 \%$ per year $(95 \%$ CI $-12.9 ;-6.4)$ (Table 2 and Fig. 1).

\section{DISCUSSION}

It was possible to observe that the Santa Catarina State and six of its nine health regions presented distinct trends in relation to the detection of hepatitis B. The first trend was a significant increase of rates in the early years of study, occurred in the state as a whole and in the far-western, northeastern, Greater Florianópolis and southern regions. In the southern region, the increase in the period from 2002 to 2006 was of a great enough magnitude ( $15.9 \%$ per year) to generate a significant increase in the period of study of $5.2 \%$ per year. The second trend was a significant decrease of rates that occurred in the state as a whole, and in Foz do Rio Itajaí, Planalto Serrano and far-western and southern regions. It is worth highlighting the fact that the regions of Foz do Rio Itajaí and Planalto Serrano had great increases in annual variations $(21.1 \%$ and $12.0 \%$, respectively) in the first period of the study, but such increases were not statistically significant. This fact may have been influenced by the small number of reported cases in these regions ( 74 and 81 , respectively). The magnitude of decrease in the Planalto Serrano from 2005 to $2009(18.0 \%$ per year) was enough to generate a significant decrease of $6.3 \%$ per year in the whole period of study. In the Vale do Rio Itajaí a single trend of decrease of $9.7 \%$ per year was observed.

Although this study does not have an explanatory methodological design, it is possible to deduce that the decrease in the rates of detection could be a reflection of programs of immunization, as well as more effective, vigilant actions towards the prevention of hepatitis $\mathrm{B}$. These 
MARCON, C.E.M.; SCHNEIDER, I.J.C. \& TRAEBERT, J. - Temporal trends in the detection rates of hepatitis B in the Santa Catarina State, Brazil. Rev. Inst. Med. Trop. Sao Paulo, 56(2): $151-5,2014$

Table 2

Variation of annual percentage in the period from 2002 to 2009 of detection rates of hepatitis B in Santa Catarina and in its health regions

\begin{tabular}{|c|c|c|c|}
\hline State and health regions & Period & $\begin{array}{l}\text { Variation of annual percentage } \\
\text { (IC 95\%) }\end{array}$ & $\begin{array}{l}\text { Variation of percentage from } 2002 \text { to } 2009 \\
\text { (IC 95\%) }\end{array}$ \\
\hline \multirow{2}{*}{ Santa Catarina } & 2002 to 2006 & $5.9 *(3.6 ; 8.3)$ & \multirow{2}{*}{$0.4(-0.8 ; 1.6)$} \\
\hline & 2006 to 2009 & $-6.4 *(-9.7 ;-3.1)$ & \\
\hline \multirow{2}{*}{ Far West } & 2002 to 2006 & $4.6^{*}(2.1 ; 7.2)$ & \multirow{2}{*}{$0.5(-0.8 ; 1.8)$} \\
\hline & 2006 to 2009 & $-4.8 *(-8.3 ;-1.1)$ & \\
\hline \multirow{2}{*}{ Foz do Rio Itajaí } & 2002 to 2004 & $21.1(-33.1 ; 119.0)$ & \multirow{2}{*}{$-11.2(-21.8 ; 0.9)$} \\
\hline & 2004 to 2009 & $-21.5^{*}(-33.5 ;-7.3)$ & \\
\hline \multirow{2}{*}{ Planalto Serrano } & 2002 to 2005 & $12.0(-5.4 ; 32.7)$ & \multirow{2}{*}{$-6.3 *(-11.9 ;-0.3)$} \\
\hline & 2005 to 2009 & $-18.0 *(-27.3 ;-7.6)$ & \\
\hline \multirow{2}{*}{ Northeast } & 2002 to 2006 & $17.4 *(6.0 ; 30.1)$ & \multirow{2}{*}{$4.9(-0.6 ; 10.7)$} \\
\hline & 2006 to 2009 & $-9.8(-22.3 ; 4.8)$ & \\
\hline \multirow{2}{*}{ Great Florianópolis } & 2002 to 2006 & $15.4 *(2.2 ; 30.4)$ & \multirow{2}{*}{$5.8(-0.6 ; 12.6)$} \\
\hline & 2006 to 2009 & $-5.8(-20.8 ; 12.0)$ & \\
\hline \multirow{2}{*}{ South } & 2002 to 2006 & $15.9 *(13.8 ; 17.9)$ & \multirow{2}{*}{$5.2 *(4.2 ; 6.2)$} \\
\hline & 2006 to 2009 & $-7.5 *(-9.8 ;-5.2)$ & \\
\hline Planalto Norte & 2002 to 2009 & $-0.6(-2.1 ; 0.8)$ & $-0.6(-2.1 ; 0.8)$ \\
\hline Mid West & 2002 to 2009 & $2.7(-3.1 ; 8.7)$ & $2.7(-3.1 ; 8.7)$ \\
\hline Vale do Itajaí & 2002 to 2009 & $-9.7 *(-12.9 ;-6.4)$ & $-9.7 *(-12.9 ;-6.4)$ \\
\hline
\end{tabular}

$* p$ - value $<0.05$.
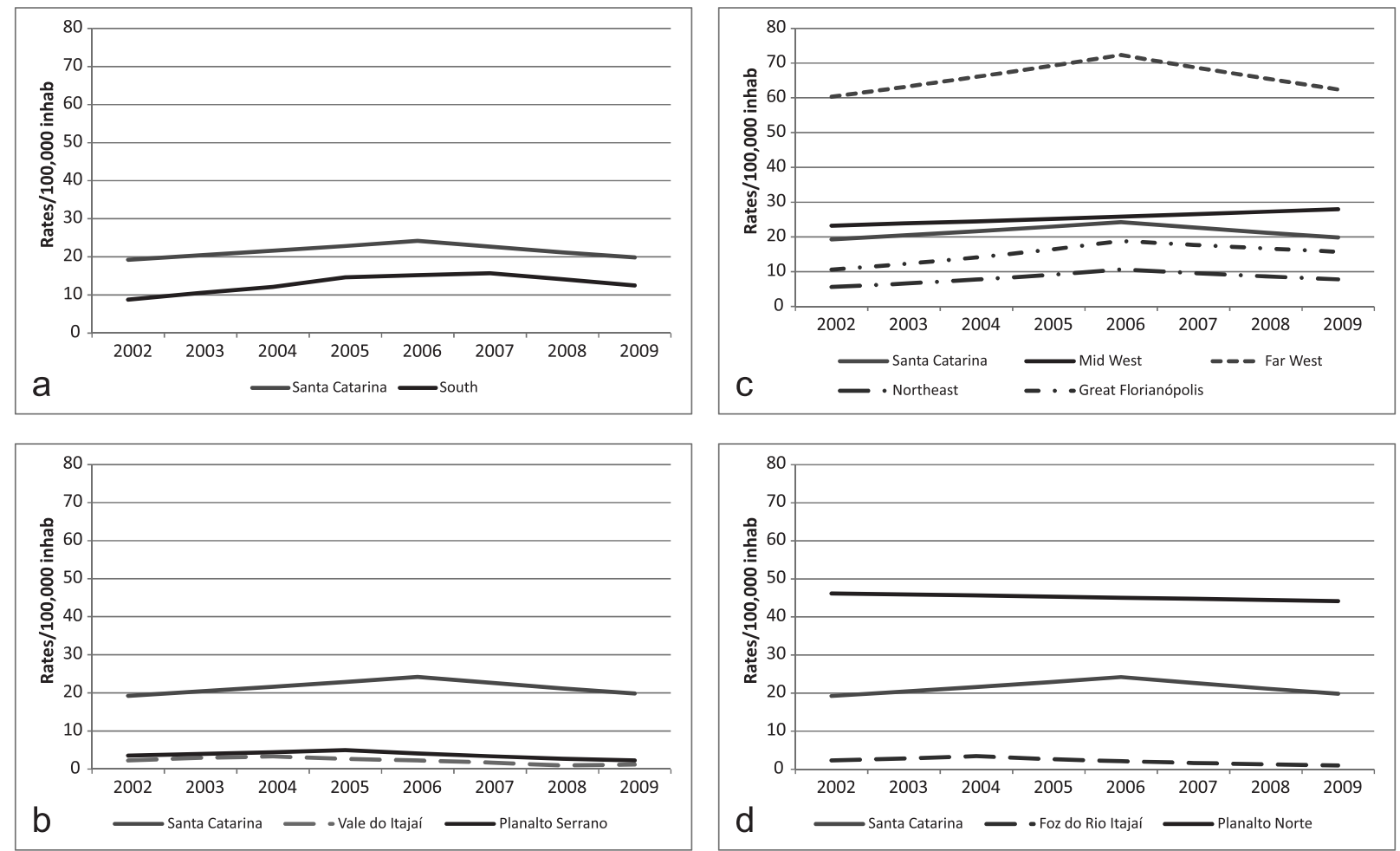

Fig. 1 - Trend of incidence rates/100 thousand inhabitants by hepatitis B in the period from 2002 to 2009 in Santa Catarina and in its health regions. a. Health region with significant increase; b. Health region with significant decrease; c. Health region with no significant increase; d. Health region with no significant decrease. 


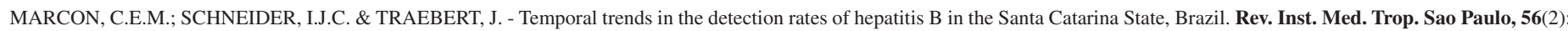
151-5, 2014

aspects provide a plausible hypothesis that explains the growing trend of rates of notification in early years of study, followed by a decreasing trend. This fact has been observed in many countries. A significant decrease of infection by hepatitis B was attributed to children who have been vaccinated since 1991 in Egypt $^{20}$ and since 1993 in Pakistan ${ }^{1}$ and in Iran for all neonates and high-risk groups ${ }^{2}$. Data reported in Italian studies indicated that the implementation of the vaccination had a great impact on the control and prevention of hepatitis B in Italy ${ }^{8,9,16}$. There was an overall decline in the HBsAg positivity rate and an overall increase in the population immunity to hepatitis B in Singapore after the implementation of the national childhood immunization programme ${ }^{14}$. The universal implementation of vaccination against the hepatitis B virus at birth has reduced its occurrence in adolescents and young adults in Taiwan ${ }^{18}$.

The immunization against HBV aims to prevent the disease and to avoid the chronification and evolution of liver cirrhosis and hepatocellular carcinoma. In Brazil the inclusion of the vaccination against hepatitis B in the public vaccination schedule has developed gradually since 1989 . Due to the high prevalence of hepatitis B in western Amazonia, the vaccination campaigns against hepatitis B were introduced in the municipalities of Purus, Boca do Acre and Lábrea. In 1991 the vaccine became part of the public vaccination schedule in the state of Amazonas. In 1992 it was made available in the states of the Legal Amazon, Paraná, Espírito Santo, Santa Catarina and the Federal District for children younger than five years old. In 1994 the vaccine was made available to healthcare professionals from the private sector, firefighters, police, military and students of medicine, dentistry, nursing and biochemistry. In 1998 the vaccine was made available to all children in the country who were less than one year old. In 2001, the vaccine was made available to people who were under 20 years old. In 2011 the age increased to 20 to 24 years. In 2012 the vaccine was made available to people aged 25-29 years and in 2013 the vaccine was extended to the age group of 30-49 years old and also for individuals over $50^{6}$.

A study carried out by the Brazilian Ministry of Health discovered that the number of confirmed cases in the country in 1996 was 8,512, with a vaccine covering $13 \%$ of children who were under one year old. In 2002, the number of confirmed cases decreased to 3,160 with a vaccine covering $89 \%$. In Santa Catarina, a study carried out in Itajaí demonstrated that the vaccine covering in adolescents was of $97.5 \%$ and the prevalence of HBsAg was of $0.6 \%{ }^{9}$.

Among different effective measures, the prevention of vertical transmission of HBV should be an important aim because the proportion of chronification is very high when hepatitis B is acquired in early years of life. In a study carried out in the state of São Paulo it was observed that the administration of immunoglobulin in neonates, often does not occur in the stipulated period of 12 hours after birth, which is a great failure in the duty of care of the newborn ${ }^{15}$.

The significant increase in the detection rates in the health region of the South highlights the importance of more effective preventative measures. More effective measures with regards to immunization should be put in place: a reduction in substance abuse, an education on the importance of the practice of safe sex, better care should be taken during the administration of blood transfusions, adequate care should be provided for babies born from HBV-infected mothers and informative campaigns about the disease should be developed. These actions should also aim to establish a wider vaccine covering, especially in adolescents and adults.

The results of this descriptive study should be viewed with caution since its design does not allow for cause-effect relationship, but rather describes the rates of detection of hepatitis B during a limited period of years. It can be concluded that the state of Santa Catarina presented two significant trends in the studied period. The first, from 2002 to 2006, was that there was a significant increase in the detection rate of $5.9 \%$ per year. From 2006 there was an inversion of the trend, with a significant decrease of $6.4 \%$ per year. This same pattern was observed in the southern and far-western health regions but with different rates. The health regions of Greater Florianópolis and the North-east also showed significant increases until 2006, but after that year, the reversal of trends was not significant. The health regions of Foz do Rio Itajaí and Planalto Serrano showed no significant increases up to the half of the studied period, with significant trend reversals. Three health regions showed a single trend. The Vale do Itajaí showed a significant decrease, the Planalto Norte had a non-significant decline and the Midwest had a non-significant increase.

\section{RESUMO}

\section{Tendência temporal da taxa de detecção de hepatite B no estado de Santa Catarina, Brasil}

A hepatite B é um grave problema de saúde pública. O estado de Santa Catarina apresenta áreas de alta endemicidade. O objetivo deste estudo foi descrever a tendência temporal da taxa de detecção de hepatite B no período de 2002 a 2009 em Santa Catarina e em suas macrorregiões. Foi realizado um estudo de séries temporais com dados de notificação. As taxas brutas foram calculadas e padronizadas por idade pelo método direto. Estimou-se a variação anual por intermédio de regressão linear segmentada. $\mathrm{O}$ estado apresentou duas tendências significativas distintas. De 2002 a 2006, observou-se aumento significativo de 5,9\% ao ano. A partir de 2006, queda significativa de 6,4\% ao ano. Também nesses períodos, as macrorregiões Sul e Extremo-Oeste apresentaram aumentos significativos de $15,9 \%$ e $4,6 \%$ e quedas significativas de $7,5 \%$ e $4,8 \%$, respectivamente. A Grande Florianópolis e o Nordeste também apresentaram aumentos significativos até 2006, de 15,4\% e $17,4 \%$ respectivamente. No período seguinte, ocorreram quedas não significativas de 5,8\% e 9,8\%, respectivamente. A Foz do Rio Itajaí e o Planalto Serrrano apresentaram aumentos não significativos até a metade do período estudado de $21,1 \%$ e $12,0 \%$, respectivamente, e depois, quedas significativas de $21,5 \%$ e $18,0 \%$, respectivamente. O Vale do Itajaí mostrou queda significativa de $9,7 \%$; o Planalto Norte, queda não significativa de $0,6 \%$ e o Meio-Oeste, aumento não significativo de 2,7\% por ano, no período de 2002 a 2009.

\section{REFERENCES}

1. Ahmed W, Qureshi H, Arif A, Alam SE. Changing trend of viral hepatitis. A twenty one year report from Pakistan Medical Research Council Research Centre, Jinnah Postgraduate Medical Centre, Karachi. J Pak Med Assoc. 2010;60:86-9.

2. Alavian SM, Fallahian F, Lankarani KB. The changing epidemiology of viral hepatites B in Iran. J Gastrointestin Liver Dis. 2007;16:403-6.

3. Aquino JA, Pegado KA, Barros LP, Machado LFA. Soroprevalência de infecções por vírus da hepatite $\mathrm{B}$ e vírus da hepatite $\mathrm{C}$ em indivíduos do estado do Pará. Rev Soc Bras Med Trop. 2008;4:334-7. 
4. Brasil. Ministério da Saúde. Secretaria de Vigilância em Saúde. Departamento de DST, Aids e Hepatites Virais. Boletim Epidemiológico. Brasília, 2012. [cited: 2013 Jun 14]. Available from: http://www.aids.gov.br/sites/default/files/anexos/ publicacao/2012/51820/boletim_epidemiol_gico_hepatites_virais_2012_ve_12026. pdf

5. Brasil. Ministério da Saúde. Secretaria de Vigilância em Saúde. Departamento de Vigilância Epidemiológica. Caderno 6. 7 ed. Brasília: Ministério da Saúde; 2005.

6. Brasil. Ministério da Saúde. Secretaria de Vigilância em Saúde. Departamento de Vigilância das Doenças Transmissíveis. Nota Técnica Conjunta N 02/2013/ CGPNI/ DEVEP e CGDHRV/DST- AIDS/SVS/MS. Brasília: Ministério da Saúde; 2013.

7. Chávez JH, Campana SG, Haas P. Panorama da hepatite B no Brasil e no estado de Santa Catarina. Rev Panam Salud Publica. 2003;14:91-6.

8. Da Villa G, Romanò L, Sepe A, Iorio R, Paribello N, Zappa A, et al. Impact of hepatitis $B$ vaccination in a highly endemic area of south Italy and long-term duration of antiHBs antibody in two cohorts of vaccinated individuals. Vaccine. 2007;25:3133-6.

9. De Paschale M, Manco MT, Belvisi L, Brando B, Latella S, Agrappi C, et al. Prevalence of markers of hepatitis B virus infection or vaccination in HBsAg-negative subjects. Blood Transfus. 2012;10:344-50.

10. Ferreira CT, Silveira TR. Hepatites virais: aspectos da epidemiologia e da prevenção. Rev Bras Epidemiol. 2004;7:473-87.

11. Ferreira CT, Silveira TR. Viral hepatitis prevention by immunization. J Pediatr (Rio J) 2006;82(3 Suppl):S55-66

12. Ferreira MS. Diagnóstico e tratamento da hepatite B. Rev Soc Bras Med Trop 2000;33:389-400.
13. Figueiredo NC, Page-Shafer K, Pereira FEL, Miranda AE. Marcadores sorológicos do vírus da hepatite B em mulheres jovens atendidas pelo Programa de Saúde da Família em Vitória, estado do Espírito Santo, 2006. Rev Soc Bras Med Trop. 2008;41:590-5.

14. Hong WW, Ang LW, Cutter J, James L, Chew SK, Goh KT. Changing seroprevalence of hepatitis B virus markers of adults in Singapore. Ann Acad Med Singapore 2010;39:591-8

15. Perim EB, Passos ADC. Hepatite B em gestantes atendidas pelo Programa do Pré- Nata da secretaria municipal de saúde de Ribeirão Preto, Brasil: prevalência da infecção e cuidados prestados aos recém- nascidos. Rev Bras Epidemiol. 2005;8:272-81.

16. Romanò L, Paladini S, Tagliacarne C, Zappa A, Zanetti AR. The changing face of the epidemiology of type A, B, and D viral hepatitis in Italy, following the implementation of vaccination. Vaccine. 2009;27:3439-42.

17. Santa Catarina. Secretaria de Estado da Saúde. Plano Estadual de Saúde 2012-2015. Florianópolis, 2011. [cited: 2013 Jun 14]. Available from: http://www.saude. sc.gov. br/materiais/ PES_2012_CES.pdf

18. Su W, Liu C, Liu D, Chen S, Huang J, Chan M. Effect of age on the incidence of acute hepatitis B after 25 years of universal newborn hepatitis B immunization program in Taiwan. J Infect Dis. 2012;205:757-61.

19. World Health Organization. Hepatite B. Geneva: World Health Organization; 2012 Available from: www who.int/mediacenter/factsheets/fs204/ES/

20. Zakaria S, Fouad R, Shaker O, Zaki S, Hashem A, El-Kamary SS, et al. Changing pattern of acute viral hepatitis at a major urban referral Center in Egypt. Clin Infect Dis. 2007;44:e30-6.

Received: 15 April 2013

Accepted: 14 August 2013 